\title{
The South African Air Force in Korea: an evaluation of 2 Squadron's first combat engagement, 19 November until 2 December 1950
}

\section{Antonio Garcia*}

\begin{abstract}
South African participation in the Korean War (1950-1953) in direct support of an international military offensive led by the United States of America demonstrated the National Party administration's commitment to opposing Communism. This article details how the deployment of South African Air Force 2 Squadron achieved the strategic objectives of the South African government in supporting the anti-communist United States-led United Nations coalition in the Korean War. It evaluates the performance of South Africa's Air Force in their first operational test since the Second World War. The combat operations discussed under the scope of this article include the first tactical engagement of 2 Squadron in support of the initial advance (19 November to 21 December) 1950 and then later, the retreat of the United Nations force.
\end{abstract}

Keywords: Cold War; Korean War; air power; South African Air Force; 2 Squadron United Nations forces.

\section{Opsomming}

Suid-Afrika se deelname aan die Koreaanse Oorlog (1950-1953), in direkte ondersteuning van 'n internasionale militêre offensief onder leiding van die Verenigde State van Amerika, het die Nasionale Party-regering se verbintenis tot die teenstand van Kommunisme getoon. Hierdie artikel beskryf hoe die ontplooiing van 2 Eskader van die Suid-Afrikaanse Lugmag die Suid-Afrikaanse regering se strategiese doelwitte bereik het deur die anti-kommunistiese Verenigde Nasies-koalisie, onder leiding van die Verenigde State, in die Koreaanse Oorlog te ondersteun. Dit beoordeel die optrede van Suid-Afrika se lugmag in hulle eerste operasionele toets sedert die Tweede Wêreldoorlog. Die gevegsoperasies wat onder die bestek van hierdie artikel bespreek word sluit die eerste taktiese optrede van 2 Eskader, ter ondersteuning van die

* Antonio Garcia is a research fellow at Stellenbosch University, Faculty of Military Science, Department of Military History. He has recently published the book The First Campaign Victory of the Great War (Helion \& Co., Warwick, 2019). Email: antoniogarcia81@yahoo.com. A word of appreciation goes to Evert Kleynhans and Will Gordon for their translation of the abstract; also to Eddie Watson, Patrick Jamieson, Gillian Armstrong, the journal editors, and the anonymous reviewers for their assistance, comment and critique. 
oorspronklike opmars (19 November-21 Desember) van 1950, en die latere terugtrek van die Verenigde Nasies-mag.

Sleutelwoorde: Koue Oorlog; Koreaanse Oorlog; lugkrag; Suid-Afrikaanse Lugmag; 2 Eskader, Verenigde Nasies-magte.

\section{Introduction}

In 1973, the eminent military historian, Sir Michael Howard, put forward the hypothesis that existing military doctrine and training would, very quickly, prove challenging or out of date during the initial combat of a new war. This article details and evaluates the performance of South African Airforce (SAAF)'s 2 Squadron, in its first tactical encounter in Korea, which took place between 19 November and 2 December 1950, and was able to integrate fully and operate effectively with an international military force during a war which lasted until 1953.

In this analysis, the success of 2 Squadron is measured in terms of the frequency of missions, the number of successful sorties flown, and its effective integration with the UN forces. For this article, two propositions regarding general military doctrine are discussed: "... first, in times of peace, armed forces imperfectly prepare for their next conflict. Second, the ability of these military forces to make adjustments to overcome this shortcoming is critical to their combat success." 1 The difficulty in applying the first principle is that the Korean War was led by the forces of the United States of America (USA) under the banner of the United Nations (UN), and thus the doctrine belonged to the Americans. The US applied its established Second World War doctrine in a consecutive war. The article shows that South African forces operated within an American doctrinal framework and details 2 Squadron's ability to make adjustments in the theatre of operations.

The archival source base for this study is largely the previously little-used South African official war diaries. These war diaries are the military's institutional memory. ${ }^{2}$ They have the inherent bias of being generated from the side of the UN forces, and are often written with studied, cold detachment; however, they can provide insight into the course of the conflict. ${ }^{3}$ They add value in the reconstruction of events and allow historians to paint a more balanced picture. The British military played a central role in the formation of the Union Defence Force, the predecessor of the South African

1. A.E. Purdham, "America's First Air Battles: Lessons Learned or Lessons Lost?" Air University, College of Aerospace Doctrine, Research and Education, Cadre Paper Series, $16,2003, \mathrm{p} 1$.

2. W.E. Feichtinger, E.M. Felberbauer and E.A. Schmidl (eds), International Crisis Management: Squaring the Circle (National Defence Academy, Vienna, 2011), p 15.

3. See, E. Kleynhans, "The War Diary as a Historical Source", Unpublished conference paper presented at the Historical Association of South Africa conference, 2012. See also Feichtinger, Felberbauer and Schmidl, International Crisis. 
Defence Force, and the South African National Defence Force, and transferred many of its doctrinal and administrative structures and processes, one of which was the war diary. This important source allows researchers to re-create 2 Squadron's first combat experience in Korea.

Previous works have focused on broader operations and themes, such as morale. This article fills a gap in analysing and reassessing the first combat experience of 2 Squadron, through the use of the "first battles" approach. Similar studies have been published on US forces in the Korean and other wars and this article builds on the work of previous scholars. The study of first battles and engagements in a new war, as shown in 1986 by C.E. Heller and W.A. Stofft, provides a lens through which to understand a military force's first preparedness and ability to evolve in any given war. ${ }^{4}$ This approach was developed further by the military scholar and officer A.E. Purdham in his thesis "America's First Air Battles". ${ }^{5}$ The performance of the South African forces is evaluated by the results of their missions. Unlike the initial combat experience, by the end of the war, the overall attrition rate of the squadron was high as a result of the acquisition of the Communist Chinese Force's (CCF) anti-air weaponry and fighter aircraft, which were absent during the first engagements. The existing historiography of 2 Squadron in the Korean War is relatively limited. Early accounts of the squadron's history emerged in the 1970s, ${ }^{6}$ while Dermot Michael Moore's work in the early 1980s on 2 Squadron's participation in the Korean War is the most comprehensive. ${ }^{7}$ Several other publications capture further detail of the operations conducted by 2 Squadron. ${ }^{8}$

4. C.E. Heller and W.A. Stofft (eds), America's First Battles 1776-1965 (University Press of Kansas, Lawrence, 1986).

5. Purdham, "America's First Air Battles".

6. Also, P.M.J. McGregor, "The History of No 2 Squadron, SAAF, in the Korean War", Military History Journal, 4, 1978, p 3. The exploits of 2 Squadron are also mentioned in South Korean Ministry of Defence, The History of the United Nations Forces in the Korean War, Volume 1 (Ministry of Defence, Seoul, 1971); and C. Scott-Shaw, Looking Back with Laughter: The Saga of a South African Student, Soldier and Skypilot in Korea (Shuter \& Shooter, Pietermaritzburg, 1973).

7. D.M. Moore, "The Role of the South African Air Force in the Korean War, 1950-1953", D Litt et Phil thesis, University of South Africa, 1982. Moore's thesis was later published by Ashanti in the "South Africans at War" series, as D.M. Moore and P. Bagshawe, South Africa's Flying Cheetahs in Korea (Ashanti, Rivonia, 1991). Also see D.M. Moore, "The SAAF in Korea", Scientia Militaria, South African Journal of Military Studies, 10, 1980, p 4; and, D.M. Moore, "The South African Air Force in Korea: An Assessment", Military History Journal, 6, 1984, p 3.

8. C.R. Owen, The South African Korea Medal Roll (Chimperie Agencies, Benoni, 1982); J.S. Bouwer and M.N. Louw, The SAAF at War 1940-1984: A Pictorial Appraisal (Chris van der Berg Publications, Johannesburg, 1989); R. Belling, A Portrait of Military Aviation in South Africa (Struikhof, Cape Town, 1989); P. Bagshawe, Warriors of the Sky: Springbok Air Heroes in Combat (Ashanti, Rivonia, 1991); R.F. Dorr, J. Lake and W. Thompson, Korean War Aces (Osprey, Oxford, 1994); W.A. Brent, "Flying Cheetahs", Korea 19501953 (Freeworld Publications, Nelspruit, 2001); P. Chapman, In All Weather: Memoirs of the Ground Crew, 2 Squadron, South African Air Force in Korea 1950 to 1953 (Just Done, Durban, 2006); C. Stannard, Beyond the Edge of the Sky: Stories from the Life of Lt 
This article fills a gap in recreating the first combat experience of 2 Squadron through an analysis of its performance and its ability to integrate into an international military force, in Korea in 1950.

\section{Background}

The termination of the Second World War (WW2) in 1945 resulted in a profound realignment of many national and international interests. The shift in global politics created a polarised world, characterised by the fall of the Iron Curtain, a term coined by Winston Churchill in his "Sinews of Peace" speech at Westminster College, Fulton, Missouri, in 1946.9 The Korean War gave the USA and its international allies the first opportunity to openly oppose Communism in combat.

The North Korean Army invaded South Korea in June 1950. This electrified the Americans into action. They lost little time in proposing a motion to the United Nations Security Council (UNSC), and the upshot was UN Resolution 82, opposing the North Korean invasion. A subsequent meeting of the UNSC led to Resolution 83, which endorsed military action in Korea, and deemed the invasion a breach of international peace and security. ${ }^{10}$ The Soviet Union would probably have vetoed the motion but was absent from that particular sitting of the Security Council. Their absence was in protest to the UN's recognition of the Taiwan-based Republic of China's seat on the Security Council as opposed to that of the People's Republic of China.

At this time, the Republic of China supported the motion (put forward by Taiwan and supported by the USA) for combat operations against North Korea. Taiwan's interests were linked to countering the threat posed by North Korea and the People's Republic of China. ${ }^{11}$ The Korean War became the first US-led international intervention of the Cold War, mandated by the UN under Chapter 7. The conflict is widely regarded as a reflection of the ideological differences of the main belligerents.

Gen Denis Earp former Chief of the SA Air Force, 1984-1988 (Crowbar, Pretoria, 2008); D. Wingrin, Tumult in the Clouds: Stories from the South African Air Force, 1920-2010 (30 Degrees South, Pinetown, 2012); A. Wessels, “The South African Air Force, 19202012: A Review of its History and an Indication of its Cultural Heritage", Scientia Militaria, 40, 2012, p 3. Some of the recent publications on the topic of 2 Squadron and the Korean War include M.D. Goldsmid, "Morale and Military Performance: A Case Study of the Second Squadron SAAF in Korea, 1950-1953", MA thesis, University of Johannesburg, 2014; and I. Van der Waag, A Military History of Modern South Africa (Jonathan Ball, Johannesburg, 2015).

9. W.S. Churchill, "The Sinews of Peace (Iron Curtain Speech)", https://winstonchurchill.org/resources/speeches/1946-1963-elder-statesman/thesinews-of-peace/ (accessed 8 May 2020).

10. UN Resolution 83, June 1950. https://undocs.org/S/RES/83(1950) (accessed 8 May 2020).

11. The independence and division of Korea came about as a result of the Allied victory in WW2 and the subsequent occupation of Korea by the Soviet and US forces respectively. The Korean War was framed by the ideological tensions of the Cold War. 
South Africa became involved in the international war effort when the UNSC requested its support in the suppression of the North Korean invasion. Initially, the South African authorities deliberated on the type and shape of military support that would be required for the mission, and indeed whether a deployment was feasible. A key consideration was the considerable geographical distance between the countries. Later, and as a result of increased local and international pressure, the National Party cabinet endorsed the deployment of a military force. ${ }^{12}$

Since its surprising election into power in 1948 and guided by the policies of its Minister of Defence, F.C. Erasmus, the apartheid government had taken a largely inward-looking approach to controlling what it termed "internal unrest" and on the "protection" of the Union of South Africa from a perceived "external threat". ${ }^{13}$ Participation in the Berlin airlift in 1948-1949 and the Korean War were notable exceptions to South Africa's mainly self-focused policies. The South African Nationalist government feared the rise of Communism and sought ties with the West to bolster "national security" through international coalition. ${ }^{14}$

While South Africa took an inward-looking approach, the international community associated with the UN and the USA questioned many of South Africa's racial policies and its administrative and territorial claim to then-South West Africa (Namibia). As a measure of appeasement, the deployment of a military force by Prime Minister D.F. Malan demonstrated solidarity with the West and diverted attention from its oppressive political policies. ${ }^{15}$ The deployment of an air force squadron was the minimum commitment required to achieve these South African objectives; however, the National Party was hesitant to commit troops to an international offensive. ${ }^{16}$ The World Wars had led to a political backlash among sectors of the Afrikaner population, and the National Party was cautious to balance local interests and international relations. The South African government was thus not particularly interested in the combat objectives of the campaign but, rather, in the more localised interests of its supporters. ${ }^{17}$

12. Moore, "The South African Air Force in Korea: An Assessment", p 1. The agreement between the different political parties in support of the Korean War was significant as they had disagreed on South African participation in the two World Wars. For an excellent political analysis. see N.M. Van der Waag-Cowling, "South Africa and the Korean War, the Politics of Involvement", Scientia Militaria, 44, 1, 2016.

13. Van der Waag, A Military History, p 224. South Africa was defensive in approach and sought international support to bolster its position against outside threats.

14. S. Sandler (ed.), The Korean War: An Encyclopaedia (Routledge, New York, 1995), p 320. For a discussion on the Union Defence Force post-1948, see L. Jooste, "F.C. Erasmus as Minister van Verdediging”, MA dissertation, University of South Africa, 1995.

15. Sandler (ed.), The Korean War, p 320.

16. W. Stueck, The Korean War: An International History (Princeton University Press, Princeton, 1995), p 74; Y. G-M. Lulat, The US Relations with South Africa: A Critical Overview from the Colonial Period to the Present (Peter Lang, New York, 2008), p 145.

17. In the 1950s, South Africa sought to rearm and retrain its military after WW2, while also addressing links with the Commonwealth and other possible multilateral links. 
Sending 2 Squadron into the fray was the minimum commitment required to achieve these objectives. ${ }^{18}$ It was a symbolic contribution to the war effort because the force was not a strategic game-changer in terms of military materiel. In this, it was a commitment like most of the other contributors to the UN effort, the largest force component of which was provided by the US. A range of countries provided forces, including, but not limited to, the United Kingdom, Canada, Australia, New Zealand and Greece.

The Korean War commenced with the North Korean invasion of South Korea on 25 June 1950. On 4 August, the South African government made an offer of a combat squadron to supplement the forces in Korea. In the last week of August, the Chief of the General Staff chose 2 Squadron as the combat capability to be contributed to the UNC. ${ }^{19}$ According to the Defence Act of 1912 and the Amendment Act, No. 22 of 1922, only volunteers could be used in military service. Accordingly, Brigadier J.T. Durrant, Director General of the Air Force, put out a call for volunteers. This was met enthusiastically by members of the permanent force and the citizen forces. 2 Squadron was mobilised and subjected to pre-deployment training and administration while the UNC executed the first phase counteroffensive in response to the North Korean invasion around June to September 1950. The first contingent of 50 officers and 157 other ranks left for the Far East on 25 September. ${ }^{20}$ The SAAF Squadron eventually entered the theatre of operations in time to support the second phase of the UNC counter-offensive which involved the advance on the Yalu River in November 1950.

The UNC counter-offensive began on 15 September with McArthur's amphibious envelopment at Inchon and operations continued for ten days. The invasion of North Korea had not been the objective at the time of the Inchon landing, but developed out of the changing situation. The UNC advance was checked when the Chinese military intervened. The first Chinese troops were detected by the UNC in late October and the CCF mounted a major counter-offensive on 26 November, pushing back the UNC offensive. The UNC retreat lasted until 25 January 1951, after which McArthur's forces regrouped and managed to regain some ground, pushing the CCF back to the vicinity of the 38th parallel. The war reached a stalemate, with lines drawn

Internally, South Africa considered matters of Afrikaner affirmative action. The 1950s showed a changing South Africa that gave the appearance of being content with the UN and the Commonwealth, while promoting apartheid - a series of racist oppressive policies that were to gain strength in the 1960s. Thanks to Eddie Watson for this point.

18. Stueck, The Korean War, p 74; Lulat, The US Relations with South Africa, p 145; Moore, "The South African Air Force in Korea: An Assessment", p 1. The agreement between the different political parties to support the Korean War was significant because they had previously disagreed on South African participation in the two World Wars.

19. Moore and Bagshawe, South Africa's Flying Cheetahs, p 1. The aircraft for the mission were purchased in the theatre of operations and thus the combat readiness of the personnel was the central concern prior to the deployment. See Moore, "The Role of the South African Air Force", p 94.

20. Moore, "The South African Air Force in Korea: An Assessment", p 1; and McGregor, "The History of No 2 Squadron", p 2. 
around the 38th parallel until the signing of the armistice and the termination of hostilities on 27 July 1953. ${ }^{21}$ The detailed tasks of 2 Squadron included fighter escorts, close support, and armed reconnaissance. ${ }^{22} 2$ Squadron's first tactical encounter took place at airfield K-24 in Pyongyang during the second phase of the UNC counteroffensive from 19 to 26 November 1950 and again in the fighting withdrawal of the UNC from 27 November until 2 December 1950. The next section provides an overview of the deployment of 2 Squadron.

\section{Deployment: The Flying Cheetahs and the operational situation in Korea}

SAAF 2 Squadron had a history of service and was responsible for shooting down 102 enemy aircraft in combat during WW2.23 Thus, many of the pilots and supporting crew had operational experience. ${ }^{24}$ of the pilots operating during the first engagements, Commandant Theron, Capt J.F.O. Davis, Capt W.J.J. Badenhorst, Capt G.B. Lipawsky, Capt H.O.M. Odendaal, Lt W.E. Wilson, Lt F.E. Potgieter and Lt E. Jones - totalling eight of the ten, had seen operational service in WW2.25 The remaining four pilots were trained and experienced, but lacked combat experience. By the end of the war, a total of 49 officers and 157 non-commissioned officers and enlisted soldiers were deployed to Korea. ${ }^{26}$ To ensure that new pilots entering the operational area received guidance, in the theatre they were often paired with pilots who had combat experience. ${ }^{27}$ This was something that the squadron would have to prove to the Americans. The insignia of 2 Squadron was a "Flying Cheetah", a symbol adopted during WW2.

21. Moore, "The Role of the South African Air Force", p 63.

22. Department of Defence Archives (hereafter DOD), War Diary South African Air Force Korea Volume 1 (hereafter WD SAAF Vol 1). Box 1. Daily entry, 17 November 1950. Moore, "Role of the South African Air Force", p 132. Armed reconnaissance involved searching a given area for targets of opportunity whether logistical or troops and then engaging them. See Moore, "The Role of the South African Air Force", p 54.

23. McGregor, "The History of No 2 Squadron"; Moore, "The Role of the South African Air Force", p 95. 2 Squadron operated in East Africa and the name "Flying Cheetahs" is derived from the unit's mascots which were two cheetah cubs. See Moore, "The Role of the South African Air Force", p 95. For more on the involvement of 2 Squadron in WW2, see B.J. Ambrose, Eagles Strike: The Campaigns of the South African Air Force in Egypt, Cyrenaica, Libya, Tunisia, Tripolitania and Madagascar, 1941-1943 (Purnell, Cape Town, 1974); H.J. Martin and N.D. Orpen, Eagles Victorious: The Operations of South African Forces over the Mediterranean and Europe, in Italy, the Balkans and the Aegean, and from Gibraltar and West Africa (Purnell, Cape Town, 1974); E. Kleynhans, "The apostles of terror": South Africa, the East African Campaign, and the Battle of El Wak", Historia, 63, 2018, p 2; E. Kleynhans, "The South African Offensive Operations in Southern Abyssinia, 1940-1941", International Journal of Military History and Historiography, 38, 2018, p 1.

24. See, Goldsmid, "Morale and Military Performance", p 105.

25. DOD: South African Air Force, Records of Service: WR 12/6865, J.F.O. Davis; WR 12/95531, G.B. Lipawsky; WR 12/19775, D. Deans; WR/1222738, W.E. Wilson; and WR12/22789, Lt E. Jones.

26. Van der Waag, A Military History, p 229.

27. See Goldsmid, "Morale and Military Performance", p 129. 
There were eighteen officers in 2 Squadron who held key command and administrative posts, as well as 32 pilots and 157 other ranks. The squadron was commanded by a WW2 ace, Commandant S. van Breda Theron. On their arrival in the Far East, 2 Squadron was placed under command of the United States Far East Air Force, ${ }^{28}$ underwent a brief conversion training course at Johnson Air Force Base, Japan $^{29}$ on 4 November 1950,30 after which an advance detachment was sent to Korea for further operational training. ${ }^{31}$ On 17 November, 2 Squadron arrived at K-9 airfield where its men were placed under the operational command of 18 Fighter Bomber Group. ${ }^{32}$ The 18 Fighter Bomber Group comprised two American squadrons, the $12^{\text {th }}$ and $67^{\text {th }}$ Fighter Bomber Squadrons, which were supported by the first detachment of 2 Squadron. ${ }^{33}$ The initial reception by the Americans was lukewarm, likely because upon the arrival of the South Africans in Japan, some elements in the US contingent were unsure about their skills and experience. However, an impressive and acrobatic aerial display by Theron soon changed their minds, and the service records of 2 Squadron's pilots provided further assurance. ${ }^{34}$ Even so, on 27 November, the South African officers reported that they were not made to feel welcome. The squadron's war diary reads: “... it cannot be said that our relationship is one of complete understanding...there was no sign of the warm and hearty feeling our officers have been accustomed to." The diary also indicated that the other ranks and ground crews received a warmer welcome. ${ }^{35} 2$ Squadron's expectations may have been shaped by their experience in working with a multinational force (a mainly British force) in WW2.

28. McGregor, "The History of No 2 Squadron", p 2; Moore, "The Role of the South African Air Force", p 95.

29. The first training flights on the F-51 Mustang were on 8 November 1950. See DOD: WD SAAF Vol 1. Box 1. Daily entry, 8 November 1950.

30. Moore, "The Role of the South African Air Force", p 112.

31. The operational training included lectures on escape and evasion, rescue mission and types and methods of attack. See DOD Archives: WD SAAF Vol 1. Box 1. Daily entry, 18 November 1950.

32. 2 Squadron was initially placed under command of 18 Fighter Bomber Group which fell under the administrative control of 6002 Tactical Support Wing. The 6002 Tactical Support Wing was replaced by 18 Fighter Bomber Wing on 1 December 1950. See Moore, "The Role of the South African Air Force", p 95; McGregor, "The History of No 2 Squadron", p 2. Note that 18 Fighter Bomber Group operated independently from 18 Fighter Bomber Wing until January 1953, see G.L. Rottman, Korean War Order of Battle: United States, UN and Communist Ground, Naval and Air Forces, 1950-1953 (Praeger, London, 2002), p 78. There were 15 Fighter Bomber Groups and Wings and 5 Tactical Support Wings, see J.I. Matray and D.W. Boose (eds), The Ashgate Research Companion to the Korean War (Ashgate, Burlington, 2014).

33. DOD: WD SAAF Vol 1. Box 1. Daily entry, 17 November 1950. 2 Squadron operated under the command of the Americans for the duration of the Korean War.

34. Anon., "The Flying Cheetahs in Korea”, SAAFA Newsletter, Bloemfontein, June 2012.

35. DOD: WD SAAF Vol 2. Box 1. Appendix B to Operation Order No2/50, 27 November 1950. 
The air operations included close support, reconnaissance, fighter escort and interdiction missions and these missions, by the end of the war, took a devastating toll on the South African forces. ${ }^{36}$ The US applied an air doctrine that was underpinned by strategic strikes, interdiction, and air superiority. There was also a focus on close air support from WW2.37 The Royal Australian Air Force contributed No 77 Squadron to the Korean War. Their early exploits were similar to those of the South Africans. Squadron Leader Dick Creswell summed it up:

We were basically doing interdiction work, armed reconnaissance and ground support roles... We were after troop concentrations, transports, bridges, T34 tanks, self-propelled guns, gun emplacements, trains, railway tunnels and stores. Our main target was transport in the early days. If we could block transport on those very tiny roads coming down from North Korea into South Korea it saved the day, for a time anyway. ${ }^{38}$

The first detachment of South African forces comprised well trained and experienced pilots, many of whom served in WW2, where air-combat, close air support, and bombing operations were carried out. The initial combat in the Korean War tested their training and experience in a new context, a new theatre of operations where technology (fighter planes MiG-15s) had evolved. The US strategic strike doctrine was superimposed on tactical doctrine, a tactic 2 Squadron was forced to adopt. ${ }^{39}$

The phases of the conflict can be broadly divided into the invasion of North Korea, the advance to the Yalu, the CCF counteroffensive and UN withdrawal, the return to the $38^{\text {th }}$ parallel, and the stalemate along the main line of resistance (MLR) (refer to Graph 1).

36. Department of Veterans' Affairs (DVA), Royal Australian Airforce in the Korean War, DVA Anzac Portal, http://anzacportal.dva.gov.au/wars-and-missions/korean-war1950-1953/korean-war/armed-forces-korean-war/royal-australian-airforce-koreanwar (accessed 18 September 2020). Comparative research of the first combat experiences of Commonwealth Squadrons in the Korean War is something that requires further attention but falls outside the scope of this article.

37. Purdham, "America's First Air Battles", pp 5-7.

38. DVA, Royal Australian Airforce in the Korean War, DVA Anzac Portal, http://anzacportal.dva.gov.au/wars-and-missions/korean-war-1950-1953/koreanwar/armed-forces-korean-war/royal-australian-airforce-korean-war (accessed 18 September 2020).

39. Goldsmid, "Morale and Military Performance", p 16. 


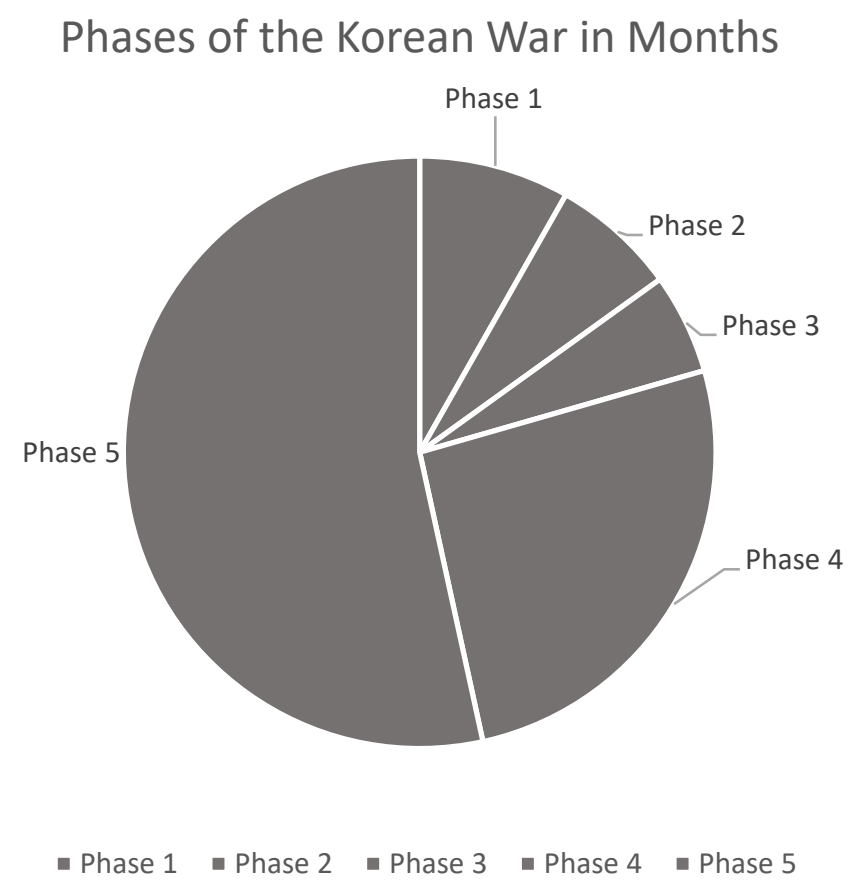

\begin{tabular}{|c|c|c|c|c|}
\hline PHASE & MAIN MOVEMENT & FROM & TO & DURATION \\
\hline ONE & The North Korean invasion & 25 Jun 1950 & $\begin{array}{l}15 \text { Sept } \\
1950\end{array}$ & 3 months \\
\hline TWO & The UN advance to the Yalu & $\begin{array}{l}15 \text { Sept } \\
1950\end{array}$ & $\begin{array}{l}25 \mathrm{Nov} \\
1950\end{array}$ & 2,5 months \\
\hline THREE & $\begin{array}{l}\text { The UN withdrawal and } \\
\text { consolidation } \\
\text { along the line P'yongt'aek - } \\
\text { Samch'ok }\end{array}$ & $\begin{array}{l}26 \text { Nov } \\
1950\end{array}$ & $\begin{array}{l}25 \mathrm{Jan} \\
1951\end{array}$ & 2 months \\
\hline FOUR & $\begin{array}{l}\text { The UN return to the } 38 \text { th } \\
\text { parallel }\end{array}$ & 25 Jan 1951 & $\begin{array}{l}12 \text { Nov } \\
1951\end{array}$ & 9,5 months \\
\hline FIVE & Stalemate along the MLR & $\begin{array}{l}12 \mathrm{Nov} \\
1951\end{array}$ & $\begin{array}{l}27 \mathrm{Jul} \\
1953\end{array}$ & 19,5 months \\
\hline
\end{tabular}

Graph 1: The Main Phases of the Korean War. ${ }^{40}$

Using the above graph, taken from Moore's study, 2 Squadron's first tactical encounter occurred during Phase 2 and 3. The first three phases of the Korean War were fluid, characterised by mobile operations from both sides. By mid-September, before the arrival of 2 Squadron, UN forces seized the initiative through the Inchon landings which allowed MacArthur to break through the Pusan perimeter forcing the North Korean forces into retreat. ${ }^{41}$ The Inchon landing severed the supply lines of the

40. Moore, "The Role of the South African Air Force", p 95; Moore, "The South African Air Force in Korea: An Assessment", p 9.

41. W.T. Y'Blood, Down in the Weeds: Close Air Support in Korea (Create Space Independent Publishers, 2015), p 18. 
North Korean forces fighting well to the south, which was the main reason for their disintegration, allowing the UN forces in the Pusan Perimeter to advance north. The UNC advance on the Yalu River was for the most part unopposed. This offensive resulted in the collapse of North Korean morale. ${ }^{42}$ Late October and early November 1950 was a tipping point in the war. China's leader Mao Ze Dong deployed an army group to Korea during October and November comprising four armies of approximately 180000 soldiers in total.

The CCF numbers increased dramatically during November 1950, which gave them the confidence to push the initiative and go on the offensive. The Chinese intervention proved problematic for the UNC and the US at the strategic, operational and tactical levels, however. ${ }^{43}$ China's support of North Korea escalated the intensity of the conflict. The role of airpower, in the pure sense, came to the fore which took the form of a UNC interdiction campaign. The US government, under President Harry S. Truman, approved the campaign in November 1950, and the interdiction mission involved 79 B-29 Bombers which then attacked bridges and key positions on the Yalu River. ${ }^{44}$ South Africa's role was focused on the tactical level in providing close air support.

\section{Squadron's first tactical encounter}

Before the CCF intervention, the UNC advance steamrolled the North Korean forces to retreat northward to the Yalu River. Many of the North Korean forces were cut off in the south or in the hills. The final UNC advance on the North Korean forces during the second phase of the war involved X Corps with support from the US 7th Infantry Division and the US 1st Marine Division. There were in effect two prongs to the advance; the main force advancing north from Pyongyang and X Corps advancing from the port of Wonsan. ${ }^{45}$ The air force advanced and occupied the North Korean airfields as the front lines moved further north. The 18 Fighter Bomber Group (to which 2 Squadron was attached) initially deployed within the Pusan perimeter (K-9) and before their relocation to K-24, had to fly a long distance to support the advancing UN forces. ${ }^{46}$ The forward element of 2 Squadron comprised five aircraft, its pilots, and

42. A. Vick, D. Orlofsky and S. Jones, The Stryker Brigade Combat Team: Rethinking Strategic Responsiveness and Assessing Deployment Options (Rand, Santa Monica, 2002), p 119.

43. A.R. Millet, "The Ground War 1948-1953", in J.I. Matravy and D.W. Boose (eds), The Ashgate Research Companion to the Korean War (Ashgate, Burlington, 2014), p 120.

44. D.M. Goldstein and H.J. Maihafer, The Korean War: The Stories and the Photographs (Potomac, Washington, 2000), p 87. The aim of air interdiction in the Korean War was to break the enemy's communication lines and cut off supplies to the front. See W.W. Momyer, Airpower in Three Wars (Air University Press, Alabama, 2003), p 173.

45. Moore, "The Role of the South African Air Force", p 127.

46. Y'Blood, Down in the Weeds, $\mathrm{p} 20$. 
supporting personnel. ${ }^{47}$ To support the advance, the movement of 18 Fighter Bomber Group was given priority. ${ }^{48}$

On 19 November 1950, 2 Squadron flew four combat sorties. The squadron's missions included close support and armed reconnaissance sorties, ${ }^{49}$ which were directed at the CCF in and around T'each'on.50 2 Squadron's F-51D Mustangs were armed with two napalm bombs, six five-inch forward-firing aircraft rockets and six $12.7 \mathrm{~mm}$ machineguns per aircraft. ${ }^{51}$ The Mustangs had been developed during WW2 but in the Korean War they were better suited for ground support rather than for air combat. The squadron's role was to provide tactical air support for the US Air Force's strategic airstrikes. As a result, the South African Air Force was required to fly low altitude, high-speed operations, which were dangerous, and often received considerable concentrations of enemy flak. ${ }^{52}$ Departing from airfield K-9 in Pusan, the South African sorties completed their missions and then landed in airfield K-24 in Pyongyang (east) in support of the advancing ground forces. ${ }^{53}$

\section{First Tactical Encounter: Stage 1}

The first 2 Squadron sortie comprised two Mustangs, piloted by Commandant Theron, the seasoned commander, and Captain G.B. Lipawsky. ${ }^{44}$ Taking off from K-9 airfield at 07:10 on 19 November, they destroyed thirteen camouflaged objects as well as five vehicles. The results of the mission were recorded as "satisfactory" in 2 Squadron's war diary. On completion of their mission, they landed in K-24.55 The recording of operations during a war is generally influenced by the norms of a given military. There is little or no space for emotion in these accounts - a factual recording was the standard practice. 56

47. DOD: WD SAAF Vol 1. Box 1. Daily entry, 18 November 1950. The rest of the 2 Squadron remained at Johnson Air Force Base in Japan.

48. DOD: WD SAAF Vol 1. Box 1. Daily entry, 18 November 1950; DOD: Archives. WD SAAF Vol 1. Box 1. Daily entry, 19 November 1950.

49. DOD: WD SAAF Vol 1. Box 1. Daily entry, 19 November 1950.

50. Moore, "The Role of the South African Air Force", p 132.

51. DOD: WD SAAF Vol 1. Box 1. Operational record, first mission, 19 November 1950.

52. Goldsmid, "Morale and Military Performance", p 164. The use of Mustangs as the aircraft of choice for close air support was less than ideal because they were soon to be outdated. See Goldsmid, "Morale and Military Performance" for a discussion on the comparison of a "strategic air force" in a tactical role and the impact on morale.

53. DOD: WD SAAF Vol 1. Box 1. Daily entry, 19 November 1950.

54. For the purposes of this research the first operational sortie in the Korean War is determined as the first mission conducted by SAAF 2 Squadron. There was one prior operational flight conducted by Commandant Pretorius, the SAAF liaison officer, who flew a bomber escort mission in early October 1950. See Moore, "The Role of the South African Air Force", p 132.

55. DOD: WD SAAF Vol 1. Box 1. Operational record, first mission, 19 November 1950.

56. This is not to say that soldiers did not experience emotion but rather that war diaries, generally, did not capture them. 
The second sortie, on 19 November, saw two Mustangs take off at 09:00 from K-9 airfield. They observed a roadblock set up by the North Koreans and Captains J.F.O. Davis and W.J.J. Badenhorst engaged it with rocket fire, destroying one vehicle. The third mission of the day was the second sortie of Theron and Lipawsky. They destroyed a building, believed to have been an ammunition dump, using napalm. ${ }^{57}$ As a part of their flight, they confirmed that the roadblock had in fact been destroyed by the previous sortie. ${ }^{58}$ The final sortie on 19 November was also a close support mission flown by Davis and Badenhorst. They attacked an enemy position on a ridge and reported that before returning to $\mathrm{K}-24$ they had observed camouflaged objects burning. ${ }^{59}$ The first operational sorties were successful and were assisted by good weather and clear visibility. Four of the squadron's five Mustangs were used for the missions on 19 November and the fifth one was ferried to K-24 airfield by Captain H.O.M. Odendaal on the same day. ${ }^{60}$ From 20 November, 2 Squadron operated from K24 until the unit was withdrawn southwards in early December 1950. 2 Squadron only conducted one operational sortie, involving 2 Mustangs commanded by pilots Odendaal and Lipawsky in a close support mission. They engaged and destroyed a train and two trucks, and the mission was described as highly successful by the US command. ${ }^{61}$

The area of 2 Squadron's operations was restricted to a narrow belt ranging from about 80 to 100 kilometres to the Yalu River. ${ }^{62}$ Two reconnaissance missions were sent out on 21 November 1950. The first mission attacked and destroyed an ammunition dump and five warehouses. The second sortie of the day was a reconnaissance mission and involved three Mustangs. No targets were engaged during the mission, but a building surrounded by barbed wire was observed. This was the first South African mission that reached the Yalu. ${ }^{63}$ On 22 November, an armed reconnaissance mission was launched and directed at targets of opportunity. ${ }^{64}$ The mission was successful and ten large warehouses were destroyed before low cloud cover compromised the pilot's visibility and forced them to return to base. ${ }^{65}$

57. Napalm is an incendiary weapon. The term "napalm" came about as a portmanteau of aluminium naphthenate and aluminium palmitate which are the essential flammable components of the explosive compound.

58. DOD: WD SAAF Vol 1. Box 1. Operational record, third mission, 19 November 1950.

59. DOD: WD SAAF Vol 1. Box 1. Operational record, fourth mission. 19 November 1950.

60. Moore, "The Role of the South African Air Force", p 132. See also DOD: WD SAAF Vol 1. Box 1. Daily entry, 19 November 1950.

61. DOD: WD SAAF Vol 1. Box 1. Operational record, first mission, 20 November 1950.

62. Moore, "The Role of the South African Air Force", p 137.

63. DOD: WD SAAF Vol 1. Box 1. Operational record, second mission. 21 November 1950.

64. Unplanned strikes are where there are no pre-selected targets.

65. DOD: WD SAAF Vol 1. Box 1. Operational record, second mission, 22 November 1950. The operational report goes on to mention that two napalm bombs were deployed. They missed the warehouses and landed in a populated area. These attacks most likely bordered the limits of acceptable collateral damage and should be considered for further investigation in terms of war crimes. 
There was only one mission conducted on 23 November 1950. This was a close support mission comprising two Mustangs piloted by Theron and Davis. The target was situated on a hill and the topography, in combination with poor visibility as well as a powerline running over the position, made for a difficult approach. The South Africans managed to strafe the position with rockets and machinegun fire. However, the results of the attack were inconclusive. ${ }^{66}$ On 24 November, the squadron was told that the UNC was planning a major offensive: this was MacArthur's "home by Christmas" offensive to complete the occupation of North Korea. The all-out offensive commenced on 24 November, ${ }^{67}$ and the war diary of 2 Squadron indicates that the men were keen to support the advance. There were indications in the war diary that most of the personnel were confident that the UNC would be successful, a perception created largely by MacArthur's claims that the conflict would end by Christmas 1950.68 The entry reads that it would have been advantageous if all aircraft had been present in $\mathrm{K}$ 24 to bolster air combat operations. ${ }^{69}$ Regardless of perceptions, the reality on the ground proved different.

The UNC offensive was limited by logistical demands and only began on 24 November. ${ }^{70} 2$ Squadron supported the UN offensive with three sorties on 24 November. The first mission was a close support mission conducted by Lipawsky and Lieutenant D. Deans. The pilots engaged and destroyed two mortar positions and killed an estimated 50 troops. The action was commended by the air controller. ${ }^{71} \mathrm{~A}$ Harvard Spotter was used as the air controller to identify targets and guide airstrikes. ${ }^{72}$ Before aerial controllers were introduced, forward air controllers operated from vehicles, although they were vulnerable to ground attack, and experienced technical problems with radio communications. The use of airborne controllers simplified communications, was safer and more efficient, and produced better results. These air

66. DOD: WD SAAF Vol 1. Box 1. Operational record, first mission, 23 November 1950.

67. B.C. Mossman, United States Army in the Korean War: Ebb and Flow November 1950-July 1951 (US Government Printing Office, Washington, 1990), p 3.

68. L.H. Brune, The Korean War: Handbook of the Literature and Research (Greenwood, London, 1996), p 412.

69. DOD: WD SAAF Vol 1. Box 1. Daily entry, 24 November 1950.

70. T.J. Gough, U.S. Army Mobilization and Logistics in the Korean War: A Research Approach (US Government Printing Office, Washington, 1987), p 77.

71. DOD: WD SAAF Vol 1. Box 1. Operational record, first, second and third missions, 24 November 1950.

72. Ground-air operations as conducted in WW2 and at the beginning of the Korean War are discussed in, War Department, FM 31-35 Basic Field Manual Aviation in Support of Ground Forces (US Government Printing Office, Washington, 1942). For more detail on the development of ground-air operations see, J. Farmer and M.J. Strumwasser, "The Evolution of the Airborne Forward Air Controller: An Analysis of Operations in Korea", United States Air Force Project Rand, Memorandum RM 5430 PR, 1967. Initially, Tactical Air Control Parties (TACPs) and Forward Air Controllers (FACs) were used to control air strikes on the front lines in accordance with ground-air operations doctrine. 
controllers were codenamed "mosquitoes" because of the call sign attached to the aircraft. ${ }^{73} 4$ Mosquito Squadron was attached to 18 Fighter Bomber Group. ${ }^{74}$

The second mission of 24 November involved two Mustangs escorting a US minesweeper. The mission eventually had to be abandoned due to engine troubles and Badenhorst and Lt. E. Jones returned to K-24. The third and final 2 Squadron mission for 24 November involved two aircraft piloted by Davis and W.E. Wilson, which destroyed two vehicles, one "camouflaged object", and a self-propelled gun. ${ }^{75}$ Despite the best efforts of the UNC, the CCF's counter-offensive, which commenced on 25 November, sent MacArthur's forces into a headlong retreat. Mao Ze Dong was fixated on a military decision and at this point was opposed to talk of a negotiated peace. ${ }^{76}$ The UNC had to undertake, in the words of Korean War historian Jonathan Pollack, "the most infamous retreat in American military history". ${ }^{77}$

The UN forces put up some resistance but after several days of combat engagement the UNC were forced to retreat. The quantity of combat aircraft was raised to three Mustangs per mission on 25 November - increasing the close support to ground operations. Lipawsky, Richter and Odendaal flew the first combat support mission and attacked a detachment of troops with inconclusive results. The second and last sortie for the day targeted a roadblock which was blocking UNC forces. The roadblock was destroyed, and an unknown number of troops were killed. ${ }^{78}$ Destroying the roadblocks allowed the UN forces to withdraw more efficiently and lowered the chances of their being ambushed. The K-23 airfield was bombed on the evening of 25 November destroying six US Air Force F-51 Mustangs. ${ }^{79}$ The aerial bombing was indicative of the impending CCF counteroffensive. The Chinese military strength north of the Yalu River reached approximately 180000 in early November. McArthur underestimated the Chinese forces, rather focusing on his plans of advance and the possibility of a conclusive victory. ${ }^{80}$

73. D.W. Boose, "The Army View of Close Air Support in the Korean War", in J. Neufeld and G.M. Watson (eds), Coalition Air Warfare in the Korean War 1950-1953 (Osprey, Maryland, 2002), p 103; and Y'Blood, Down in the Weeds, p 9.

74. DOD: WD SAAF Vol 1. Box 1. Daily entry, 21 November 1950.

75. DOD: WD SAAF Vol 1. Box 1. Operational record, first, second and third missions, 24 November 1950.

76. C. Jian, China's Road to the Korean War: The Making of the Sino-American Confrontation (Columbia University Press, New York, 1994), p 212.

77. Jonathan Pollack, quoted in P.M. Edwards, United Nations Participants in the Korean War: 45 Contributions of 45 Member Countries (McFarland \& Co., Jefferson: NC, 2013), p 54; and Jian, China's Road, p 212.

78. DOD: WD SAAF Vol 1. Box 1. Operational record, first and second missions, 25 November 1950.

79. DOD: WD SAAF Vol 1. Box 1. Daily entry, 25 November 1950.

80. D. Vego, Joint Operational Warfare: Theory and Practice (Naval War College Press, Newport, 2007), pp viii, 31. 
Mao ordered the Chinese forces on the North Korean border to be on the defensive until they had adequate air support. UNC air superiority was a central concern for the CCF. Mao entered discussions with Stalin for the provision of Soviet aircraft to support the Chinese ground forces. The appearance of MIG-15s in November 1950 was a clear indication of Russian involvement.81 This challenged the UNC air superiority, and 2 Squadron became aware of the MIG-15 threat when they were spotted on 26 November, which coincided with the bombing of K-23 airfield. ${ }^{82}$ The pilots of 2 Squadron were very concerned about the appearance of MIGs and, with good reason, they were convinced that their Mustangs were not up to the challenge of defeating MIG-15s. Goldsmid goes on to say "the South Africans realised that they could never outrun the communist jets, and so utilised the tight, low altitude, slow turning circles of the Mustang". ${ }^{3}$ SAAF service personnel penned their concerns in a letter that was later read to the House of Assembly. The letter put forward that "South African pilots felt they were at a distinct disadvantage when they compared their aircraft with the Communist jets". ${ }^{4}$ The conflict entered a high-intensity phase from 25 November 1950 until January 1951. The number of aircraft per mission was increased and most missions were close-support sorties.

\section{First Tactical Encounter: Stage 2}

The CCF counter-offensive destabilised the UNC ground forces. However, UN forces maintained air superiority and conducted close support as well as air interdiction missions. 85 The air operations of 26 November involved two close support missions of three aircraft each. The first sortie was piloted by Davis, Badenhorst and Wilson, who attacked a troop position with inconclusive results. The sortie missed the target with their napalm; however, they deployed their rockets and conducted strafing runs. The second close support mission was more successful in finding targets. Three buildings were destroyed and a troop entrenchment was napalmed, killing an estimated 300 soldiers. ${ }^{86}$

81. X. Zhang, Red Wings over the Yalu: China, the Soviet Union and the Air War in Korea (Texas A \& M University Press, College Station, 2002) pp 74-79.

82. DOD: WD SAAF Vol 1. Box 1. Daily entry, 26 November 1950. See also R.F. Futrell, US Air Force in Korea, 1950-1953 (US Govt Printer, Washington, 1996), p 285; and K.P. Werrell, Sabres over MiG Alley: The F-86 and the Battle for Air Superiority in Korea (Naval Institute Press, Annapolis, 2005).

83. Goldsmid, "Morale and Military Performance", p 110.

84. Moore, "The Role of the South African Air Force", p 79. Also referenced in Goldsmid, "Morale and Military Performance", p 110.

85. Moore, "The Role of the South African Air Force", p 152.

86. DOD: WD SAAF Vol 1. Box 1. Operational record, first and second missions, 26 November 1950. 
On 27 November, 2 Squadron provided the maximum sorties, three close support missions, to cover the retreat of the UNC ground forces. ${ }^{87}$ McArthur met with his subordinate commanders in Tokyo on 28 November. The main consideration was the preservation of as much of the UNC ground forces as possible. ${ }^{88}$ The gravity of the situation dawned on the soldiers of the K-24 base when the station commander told all personnel to be on standby for a rapid withdrawal. There was only one close support mission on 28 November which incorporated all the serviceable Mustangs available in 2 Squadron. The squadron attacked a village and destroyed an undetermined number of warehouses as well as nine vehicles, and killed a large number of troops. ${ }^{89}$

On 29 November, 2 Squadron continued with close support missions, carrying out three missions to shield the retreating UNC forces. The first two missions were directed against troop positions, which achieved inconclusive results. The third close support mission destroyed fifteen buildings and killed many troops. ${ }^{90}$ The encroaching CCF offensive hit close to home when on 29 November an attempt was made on the life of the station commander at K-23.91 By late November the situation in Korea was crystallising and it became apparent that the air force was one of the few offensive elements left at the disposal of the UN. The SAAF pilots and supporting crew worked around the clock to repair runways and aircraft. ${ }^{92} 2$ Squadron's war diary includes a commendation for the armourers who managed to keep the Mustangs armed under gruelling conditions and with a lack of tools and equipment. ${ }^{93}$

A disappointed 2 Squadron team described the retreating UNC ground forces as "pathetic". The discussions between the SAAF and the Army units that retreated past K-24 in late November 1950 mention the weary accounts by UNC forces that had been ambushed and attacked without mercy. In summing up the situation, 2 Squadron's war diary is melancholy: "... this war is surely going the wrong way". ${ }^{94}$ There was no respite for the UNC forces on 30 November. and close air missions were deployed continuously in attempts to cover the UN retreat. McArthur's "home before Christmas offensive" was now an impossibility. On 30 November, 2 Squadron conducted four close support missions aimed at stemming the flow of communist forces at strategic bridges. ${ }^{95}$ The preservation of the UN forces was MacArthur's main concern and any attempt to slow the advance of the CCF won time and space for the UNC.

87. DOD: WD SAAF Vol 1. Box 1. Operational record, first and second missions, 27 November 1950.

88. Moore, "The Role of the South African Air Force", p 142.

89. DOD: WD SAAF Vol 1. Box 1. Operational record, first mission and second missions, 28 November 1950.

90. DOD: WD SAAF Vol 1. Box 1. Operational record, first second and third missions, 29 November 1950.

91. DOD: WD SAAF Vol 1. Box 1. Daily entry, 29 November 1950.

92. McGregor, "The History of No 2 Squadron", p 4.

93. DOD: WD SAAF Vol 1. Box 1. Daily entry, 28 November 1950.

94. DOD: WD SAAF Vol 1. Box 1. Daily entry, 29 November 1950.

95. DOD: WD SAAF Vol 1. Box 1. Operational record, first second, third and fourth missions, 30 November 1950. 
The UNC retreat continued on all fronts on 1 December. The War Diary notes that the SAAF staff in Johnson's Base discussed the widely-publicised military option of using atomic weapons. ${ }^{96}$ On 30 November 1950 in a press conference, Truman had stated that the USA would consider all military means including the atomic bomb in the face of the communist onslaught. 97 The forward detachment of 2 Squadron did not have the luxury of time to consider the political commentary - theirs was a more practical approach. Three close support missions were conducted on 1 December as well as one test flight. The three close support missions were directed exclusively against enemy troop concentrations and they were all reported as successful. ${ }^{98} 2$ Squadron withdrew to K-13 at Suwon on 2 December. ${ }^{99}$

On 2 December, the forward element of 2 Squadron conducted one close support sortie. The mission targeted UNC equipment left behind during the retreat to prevent it from falling into CCF hands - 15 vehicles were destroyed.100 This marked the end of 2 Squadron's first tactical experience in the Korean War. None of the pilots involved in the first tactical encounter were killed during the initial period.

\section{Analysis and aftermath}

SAAF 2 Squadron's first tactical experience in the Korean War was in the advance of the UNC up to the Yalu River and the subsequent communist counter-offensive that resulted in the retreat of the UN forces. The UNC air force supported ground operations in the advance and their retreat by means of close support, interdiction, reconnaissance and rescue missions. 2 Squadron slotted in with the broader UNC ground and air missions and experienced no casualties during their first combat experience in the Korean War. The missions were led by the more experienced pilots who were usually the captains of the squadron. The absence of casualties during the first battles was related to the Chinese lack of air support, and the ability of the pilots. However, when the CCF received Soviet aircraft and anti-air weapons, following the initial engagement, SAAF casualties rose significantly. ${ }^{101}$

During the Korean War, over 800 South African men at arms (264 officers and 555 other ranks) were employed in the theatre of operations. ${ }^{102}$ The Americans equipped 2 Squadron with P-51 Mustangs, but the squadron later converted to the F86 Sabre. The squadron flew over 12000 sorties, in dangerous close support operations. The first detachment, which reached the combat zone in P'yongyang,

96. DOD: 2 Squadron War Diary (hereafter 2 Sqn WD). Group 1. Box 3. Daily entry, 1 December 1950.

97. M. Hastings, The Korean War (Simon \& Schuster, New York, 1987), p 179.

98. DOD: 2 Squadron War Operational Register (hereafter 2 Sqn OR). Group 1. Box 1. Operational record, first, second, third and fourth missions, 1 December 1950.

99. DOD: 2 Sqn WD. Group 1. Box 3. Daily entry, 1 December 1950.

100. DOD: 2 Sqn OR. Group 1. Box 1. Operational record, first mission, 2 December 1950.

101. Moore, "The Role of the South African Air Force", p 152.

102. Moore, "The Role of the South African Air Force", p ii. 
comprised 13 officers and 21 supporting personnel. ${ }^{103}$ Throughout the war, there was a high casualty rate with 36 killed or missing, and 79 planes lost. ${ }^{104}$

Capt J.F.O. Davis and Capt W.J.J. Badenhorst, veterans of 2 Squadron's first tactical engagements, were later killed in action. Davis died while on a close air support mission in March 1951. He was the recipient of the Distinguished Flying Cross. ${ }^{105}$ Badenhorst had a distinguished career, having served in WW2 and as a flight instructor. He had participated in 2 Squadron's first combat engagement and received the US Air Medal for his efforts. His citation reads:

By successfully completing numerous combat missions in F-51 type fighter aircraft from 19 November 1950 to 30 November 1950 he greatly enhanced the efforts of the United Nations Forces ... By his display of aeronautical skill and intrepid aggressiveness, Captain Badenhorst proved to be a credit to himself and the United States Air Force. His actions are in keeping with the high tradition of the South African Air Force. 106

Badenhorst went on to achieve three oak clusters and a Distinguished Flying Cross. He served in combat operations until he was shot down and killed in action by anti-aircraft fire in March 1951. Theron, in a moving letter to Badenhorst's wife Bobbie, wrote:

It is impossible for me to find words to express the innermost feelings of myself and the members of the squadron in this sad hour. Badie being reported missing on operations came as a great shock to us all, and we fully realise what a terrible blow it must be to you. I can assure you Bobbie, that you and the children are constantly in our thoughts...107

All the men who served in the first combat received the UN Korean War medal.108 Wilson died during the course of the Korean War but the remainder of the grouping survived. H.O.M Odendaal, in some ways a larger-than-life soldier and fighter pilot, was a veteran of WW2 who was shot down in Yugoslavia. He survived, joined the partisans, and later re-joined his squadron. He received the British and US Distinguished Flying Cross and went on to become the Inspector General of the SAAF. 109

103. DOD: WD SAAF Vol 2. Box 1. 2 Squadron SAAF employment on operations, 9 November 1950.

104. Moore, "The Role of the South African Air Force", p i.

105. The South African War Graves Project, http://southafricawargraves.org/lists/saborder d.htm (accessed 19 April 2020).

106. Dix Noonan Webb (Auctioneers) Capt Badenhorst's medals and citations, auction, 8 December 2016, https://www.dnw.co.uk/auction-archive/past-catalogues/lot.php? auction id=448\&lot uid=284299 (accessed on 19 April 2020).

107. Dix Noonan Webb (Auctioneers) Capt Badenhorst's medals and citations online as above. See also DOD: 2 Sqn WD; and Moore, "The Role of the South African Air Force".

108. Moore, "The Role of the South African Air Force", pp 457-470.

109. H.O.M. "Tank" Odendaal: DFC \& bar, DFC (U.S.A), http://tankodendaal.com/index.html (accessed 19 April 2020). 
During 2 Squadron's first tactical engagement in the Korean War from 19 November until 2 December, 33 missions were flown, of which 32 were combat sorties and one was a training flight. The bulk of the squadron's combat sorties were close support missions numbering 27. The remainder of the missions included one escort and four reconnaissance sorties. ${ }^{110}$

Of the 32 combat missions, 28 were reported as successful. The close air support aimed to destroy enemy forces and infrastructure. Statistical analysis of the first tactical engagement shows that the pilots experienced good weather and clear visibility on 31 of their 32 combat missions. On the one occasion where visibility was poor, the sortie was carrying out a reconnaissance mission, and although the pilots were unable to complete their mission, they destroyed a number of opportunity targets. The squadron experienced no opposition during their first engagement, which accounts for the low casualty rate. The unsuccessful missions include an escort flight where the aircraft experienced technical problems, and two close support missions where the results of the attacks were inconclusive. The total flying time for the first battles was 8435 minutes (approximately 140 hours).111

SAAF 2 Squadron adapted to the operational requirements of the UNC and made a valuable contribution as part of the Far East Air Force. The efforts and valour of the SAAF was commended by the US Air Force. Although the SAAF officers on the front complained of a frosty welcome, 2 Squadron slowly won the respect of their American allies. By the end of 2 Squadron's first tactical engagement by 2 December 1950, they had won the respect of the Americans and gained a reputation for aggression and grit. ${ }^{112}$ The integration of 2 Squadron with an international military force, their success rate and frequency of missions is evidence that South African training and doctrine was suitable and transferable in a new war. This finding echoes the results of the US Air Force's study of their first engagement in the Korean War. The US tactical doctrine was found to be suitable although the forces on the ground had to make small adjustments in the evolving context of the theatre. ${ }^{113} 2$ Squadron's first engagement set the scene for their deployment throughout the rest of the war.

110. DOD: WD SAAF Vol 1. Box 1. Operational record, 19-30 November 1950; DOD: 2 Sqn OR. Group 1. Box 1. Operational record, 1-2 December 1950.

111. DOD: WD SAAF Vol 1. Box 1. Operational record, 19-30 November 1950; DOD: 2 Sqn OR. Group 1. Box 1. Operational record, 1-2 December 1950.

112. Moore, "The Role of the South African Air Force", p ii.

113. Purdham, “America's First Air Battles", p 22. 
Eminent South African military historian Ian Van der Waag has assessed the historical significance of 2 Squadron's efforts as follows:

If the Korean War ushered in a new era for the armed forces of the Commonwealth as a whole, it very much represented the close of a period in the history of the UDF. It was the last time the Union was to act in concert with the Commonwealth defence structure. ${ }^{114}$

The squadron received several awards including presidential citations from South Korea and the USA. The commander of 18 Fighter Bomber Wing gave an order that:

\begin{abstract}
In memory of our gallant South African Comrades, it is hereby established as a new policy, that at all Retreat Ceremonies held by this Wing, the playing of our National Anthem shall be preceded by playing the introductory bars of the South African National Anthem, Die Stem van Suid-Afrika. All personnel of this Wing will render the same honours to this anthem as our own.115
\end{abstract}

SAAF 2 Squadron served diligently until the 1953 armistice. The power and force of the communist invasion lost momentum in mid-1951 when the UNC consolidated their retreat and made a defensive stand. By November 1951, the UNC managed to advance to approximately the 38 $8^{\text {th }}$ Parallel (the UNC did not advance as far as the $38^{\text {th }}$ Parallel in the west but went beyond it in the east), which was where the war remained until the end of hostilities. The South African aviators and their support crews observed how the Korean conflict moved from a highly mobile war to a stalemate. In late December 1952, the SAAF made a conversion to the Sabre F-86 jet fighter and after a brief stint doing counter air operations returned to its ground attack role. ${ }^{116}$

For the most part, the UN forces were deployed in a defensive role from late 1951 to July 1953 . This period is widely referred to as the stalemate. Due to political considerations, the use of ground forces was restricted from November 1951 onwards and airpower was used in a strategic role in an attempt to bring the conflict to a conclusion. ${ }^{117}$ Political discussions continued, and the war ended without a decisive result. As a consequence, the true value of air power in a strategic role was never overwhelmingly proven. ${ }^{118}$ The Korean War was the first direct engagement between the West and the Communist Bloc during the Cold War. Ultimately it became a limited war fought for limited objectives. ${ }^{119}$ In 1952, South Africa contributed five Army

114. Van der Waag, A Military History, 232.

115. Anon., https://www.globalsecurity.org/military/world/rsa/sqn-2.htm (accessed 20 September 2020); McGregor, "The History of No 2 Squadron".

116. Moore, "The Role of the South African Air Force", p ii.

117. Armistice talks were underway but also eventually stalemated on the issue of return of POWs.

118. See, K.P. Werrell, Death from the Heavens: A History of Strategic Bombing (Naval Institute Press, Annapolis, 2009).

119. D.W. Boose, US Army Forces in the Korean War (Osprey, New York, 2005), p 89; Hastings, The Korean War, p 338. For discussion on limited versus total objectives see, 
officers to the Commonwealth forces, and they served in a range of roles. This was largely a gesture to show solidarity with the international community. ${ }^{120}$

\section{Conclusion}

The aim of this article is to detail and evaluate SAAF 2 Squadron's first tactical encounter in the Korean War, from 19 November to 2 December 1950, as well as to determine the squadron's ability to integrate with a multinational force. It fills a gap in the historiography in that it provides a detailed evaluation of 2 Squadron's combat experience through the use of war diaries and "first battles" theory. The study of first battles and engagements considers the hypothesis that doctrine and training would prove challenging at any moment or out of date during the initial combat of a new war. However, this article shows that this was not the case for 2 Squadron. ${ }^{121}$ The application of the first battles theory to this article considers that the South African force was small when compared to the overall war effort. At the tactical level, however, the South African Air Force's doctrine and training proved adequate, and this position is supported by the evidence put forward in the article. This finding echoes the view that the US Air Force's doctrine and training was adequate during their initial engagement in the Korean War. ${ }^{122}$

The participation of 2 Squadron, with its support personnel and several other staff appointments, is generally considered to be a limited contribution to the overall war effort. However, it should be clarified that the relative size of the South African force matched other international contributions and their deployment contributed both to the strategic aims of the war and to the political objectives of South Africa. On this occasion, there was an overlap between the aims of the USA and those of the South African apartheid government. 123

Initially, 2 Squadron experienced difficulty integrating with the US force, but with time it achieved an excellent reputation. The deployment of 2 Squadron showed that South Africans could contribute effectively to a multinational military action. This was a continuation of the proud service delivered in WW2. The commendations and honours received are testament to their ability, and 2 Squadron memorials can be found in many countries including the USA, South Korea, and South Africa. On the

S.D. Bakich, Success and Failure in Limited War: Information and Strategy in the Korean, Vietnam, Persian Gulf and Iraqi Wars (University of Chicago Press, Chicago, 2014); B. Brodie (ed.), Strategy in the Missile Age (Rand, Princeton, 2015).

120. Van der Waag, A Military History, p 232.

121. Purdham, "America's First Air Battles", p 1; Heller and Stofft (eds), America's First Battles.

122. Purdham, "America's First Air Battles", p 22.

123. The South African Air Force was small and the contribution of a squadron, in relative terms, represented a considerable contribution for the South African government. An alternative view is that the impact of 2Squadron throughout the duration of the shooting war, although outside of the scope of this article, shows a force that made a significant impact: Eddie Watson is acknowledged for his insightful comment. 
political level, South Africa aligned itself with the West in contributing a military force to the UNC. Politically, the contribution of an air force squadron showed solidarity with the West to balance South African and international objectives. Within the broader strategic framework, SAAF 2 Squadron carried out tactical missions with grit and determination, and a high attrition rate - their efforts gained the respect and commendation of the US Airforce. ${ }^{124}$

\section{REFERENCES}

Ambrose, B.J., Eagles Strike: The Campaigns of the South African Air Force in Egypt, Cyrenaica, Libya, Tunisia, Tripolitania and Madagascar, 1941-1943 (Purnell, Cape Town, 1974).

Anon., https://www.globalsecurity.org/military/world/rsa/sqn-2.htm.

Anon., "The Flying Cheetahs in Korea", SAAFA Newsletter, Bloemfontein, June 2012.

Bagshawe, P., Warriors of the Sky: Springbok Air Heroes in Combat (Ashanti, Rivonia, 1991).

Bakich, S.D., Success and Failure in Limited War: Information and Strategy in the Korean, Vietnam, Persian Gulfand Iraqi Wars (University of Chicago Press, Chicago, 2014).

Belling, R., A Portrait of Military Aviation in South Africa (Struikhof, Cape Town, 1989).

Boose, D.W., "The Army View of Close Air Support in the Korean War", in Neufeld, J., and Watson, G.M. (eds), Coalition Air Warfare in the Korean War, 1950-1953 (Osprey, Maryland, 2002).

Boose, D.W., US Army Forces in the Korean War (Osprey, New York, 2005).

Bouwer, J.S. and Louw, M.N., The SAAF at War 1940-1984: A Pictorial Appraisal (Chris Van der Berg Publications, Johannesburg, 1989).

Brent, W.A., "Flying Cheetahs" Korea 1950-1953 (Freeworld Publications, Nelspruit, 2001).

Brodie, B. (ed.), Strategy in the Missile Age (Rand, Princeton, 2015).

Brune, L.H., The Korean War: Handbook of the Literature and Research (Greenwood, London, 1996).

Chapman, P., In All Weather: Memoirs of the Ground Crew, 2 Squadron, South African Air Force, in Korea 1950 to 1953 (Just Done Publications, Durban, 2006).

Department of Veterans' Affairs, Royal Australian Airforce in the Korean War, DVA Anzac Portal, http://anzacportal.dva.gov.au/wars-and-missions/korean-war1950-1953/korean-war/armed-forces-korean-war/royal-australian-airforcekorean-war.

Dix Noonan Webb (Auctioneers), Capt Badehorst's medals and citations, Auction, 8

December 2016, https://www.dnw.co.uk/auctionarchive/pastcatalogues/lot.php? auction id=448\&lot uid=284299.

Dorr, R.F., Lake, J., and Thompson, W., Korean War Aces (Osprey, Oxford, 1994).

Edwards, P.M., United Nations Participants in the Korean War: 45 Contributions of 45 Member Countries (McFarland \& Company, Jefferson: NC, 2013).

124. *Moore, "The Role of the South African Air Force", pp 446-448. 
Farmer, J. and Strumwasser, M.J., "The Evolution of the Airborne Forward Air Controller: An Analysis of Operations in Korea", United States Air Force Project Rand, Memorandum RM 5430 PR (1967).

Feichtinger, W.E., Felberbauer, E.M. and Schmidl, E.A (eds) International Crisis Management: Squaring the Circle (National Defence Academy, Vienna, 2011).

Futrell, R.F., The United States Air Force in Korea, 1950-1953 (US Government Printing Office, Washington, 1996).

Goldsmid, M.D., "Morale and Military Performance: A Case Study of the Second Squadron South African Air Force in Korea, 1950-1953", MA thesis, University of Johannesburg, 2014.

Goldstein, D.M. and Maihafer, H.J., The Korean War: The Stories and the Photographs (Potomac, Washington, 2000).

Gough, T.J., U.S. Army Mobilization and Logistics in the Korean War: A Research Approach (US Government Printing Office, Washington,1987).

Hastings, M., The Korean War (Simon \& Schuster, New York,1987).

Heller, C.E. and Stofft, W.A. (eds), America's First Battles, 1776-1965 (University Press of Kansas, Lawrence, 1986).

H.O.M. "Tank" Odendaal: DFC \& bar, DFC (USA), http://tankodendaal.com/index.html.

Jian, C., China's Road to the Korean War: The Making of the Sino-American Confrontation (Columbia University Press, New York, 1994).

Jooste, L., "F.C. Erasmus as Minister van Verdediging", MA dissertation, University of South Africa, 1995.

Kleynhans, E., "The 'apostles of terror': South Africa, the East African Campaign, and the Battle of El Wak", Historia, 63 (2018).

Kleynhans, E., "The South African Offensive Operations in Southern Abyssinia, 19401941", International Journal of Military History and Historiography, 38 (2018).

Kleynhans, E., "The War Diary as a Historical Source", Unpublished conference paper presented at the Historical Association of South Africa, 2012.

Lulat, Y. G-M., The United States Relations with South Africa: A Critical Overview from the Colonial Period to the Present (Peter Lang, New York, 2008).

Martin, H.J. and Orpen, N.D., Eagles Victorious: The Operations of South African Forces over the Mediterranean and Europe, in Italy, the Balkans and the Aegean, and from Gibraltar and West Africa (Purnell, Cape Town, 1974).

Matray, J.I. and Boose, D.W. (eds), The Ashgate Research Companion to the Korean War (Ashgate, Burlington, 2014).

McGregor, P.M.J., "The History of No 2 Squadron, SAAF, in the Korean War", Military History Journal, 4 (1978).

Millet, A.R., "The Ground War 1948-1953", in Matray, J.I. and Boose, D.W. (eds), The Ashgate Research Companion to the Korean War (Ashgate, Burlington, 2014).

Momyer, W.W., Airpower in Three Wars (Air University Press, Alabama, 2003).

Moore, D.M., "The Role of the South African Air Force in the Korean War, 1950-1953", D Litt et Phil thesis, University of South Africa, 1982.

Moore, D.M., "The SAAF in Korea", Scientia Militaria, South African Journal of Military Studies, 10 (1980).

Moore, D.M., "The South African Air Force in Korea: An Assessment”, Military History Journal, 6 (1984). 
Moore, D.M. and Bagshawe, P., South Africa's Flying Cheetahs in Korea (Ashanti, Rivonia, 1991).

Mossman, B.C., United States Army in the Korean War: Ebb and Flow November 1950July 1951 (US Government Printing Office, Washington, 1990).

Owen, C.R., The South African Korea Medal Roll (Chimperie, Benoni, 1982).

Purdham, A.E., “America's First Air Battles Lessons Learned or Lessons Lost?' Air University, College of Aerospace Doctrine, Research and Education, Cadre Paper Series, 16 (2003).

Rottman, G.L., Korean War Order of Battle: United States, UN and Communist Ground, Naval and Air Forces, 1950-1953 (Praeger, London, 2002).

Sandler, S. (ed.), The Korean War: An Encyclopaedia (Routledge, New York, 1995).

Scott-Shaw, C., Looking Back with Laughter: The Saga of a South African Student, Soldier and Skypilot in Korea (Shuter \& Shooter, Pietermaritzburg, 1973).

South Korean Ministry of Defence, The History of the United Nations Forces in the Korean War, Volume 1 (Ministry of Defence, Seoul, 1971).

Stannard, C., Beyond the Edge of the Sky: Stories from the Life of Lt Gen Denis Earp former Chief of the SA Air Force 1984-1988 (Crowbar Enterprises, Pretoria, 2008).

Stueck, W., The Korean War: An International History (Princeton University Press, Princeton, 1995). The South African War Graves Project, http://southafricawargraves.org/lists/saborder d.htm.

UN Resolution 83, June 1950. https://undocs.org/S/RES/83(1950).

Van der Waag, I., A Military History of Modern South Africa (Jonathan Ball Publishers, Johannesburg, 2015).

Van der Waag-Cowling, N.M., "South Africa and the Korean War, the Politics of Involvement", Scientia Militaria, 44, 1 (2016).

Vego, D., Joint Operational Warfare: Theory and Practice (Naval War College Press, Newport, 2007).

Vick, A., Orlofsky, D. and Jones, S., The Stryker Brigade Combat Team: Rethinking Strategic Responsiveness and Assessing Deployment (Rand, Santa Monica, 2002).

W. Churchill, "The Sinews of Peace (Iron Curtain Speech)", https://winstonchurchill.org/resources/speeches/1946-1963-elderstatesman/the-sinews-of-peace/ (accessed 8 May 2020).

War Department, FM 31-35 Basic Field Manual Aviation in Support of Ground Forces, (US Government Printing Office, Washington, 1942).

Werrell, K.P., Death from the Heavens: A History of Strategic Bombing (Naval Institute Press, Annapolis, 2009).

Werrell, K.P., Sabres over MiG Alley: The F-86 and the Battle for Air Superiority in Korea (Naval Institute Press, Annapolis, 2005).

Wessels, A., "The South African Air Force, 1920-2012: A Review of its History and an Indication of its Cultural Heritage", Scientia Militaria, 40 (2012).

Wingrin, D., Tumult in the Clouds: Stories from the South African Air Force 1920-2010 (30 Degrees South, Pinetown, 2012).

Y'Blood, W.T., Down in the Weeds: Close Air Support in Korea (Create Space Independent Publishers, 2015).

Zhang, X., Red Wings over the Yalu: China, the Soviet Union and the Air War in Korea (Texas A \& M University Press, College Station, 2002). 